\title{
Performance of chicks subjected to thermal challenge
}

\author{
Patrícia Ferreira Ponciano Ferraz ${ }^{(1)}$, Tadayuki Yanagi Junior(1), \\ Renato Ribeiro de Lima ${ }^{(2)}$, Gabriel Araújo e Silva Ferraz ${ }^{(1)}$ and Hongwei Xin ${ }^{(3)}$
}

\begin{abstract}
(1)Universidade Federal de Lavras (Ufla), Departamento de Engenharia, Caixa Postal 3037, CEP 37200-000 Lavras, MG, Brazil. E-mail: patricia.ponciano@deg.ufla.br, yanagi@deg.ufla.br, gabriel.ferraz@deg.ufla.br (2)Ufla, Departamento de Ciências Exatas, Caixa Postal 3037, CEP 37200-000 Lavras, MG, Brazil. E-mail: rrlima@dex.ufla.br ${ }^{(3)}$ Iowa State University, Department of Agricultural and Biosystems Engineering, 1340 Elings Hall, 605 Bissel Road, 50011-3310 Ames, lowa, United States. E-mail: hxin@iastate.edu
\end{abstract}

\begin{abstract}
The objective of this work was to evaluate the effect of thermal challenge at different intensities and durations on the production responses of 3 to 21-day-old broiler chickens. Two hundred and ten Cobb chicks were subjected to dry-bulb temperatures $\left(\mathrm{t}_{\mathrm{db}}\right)$ of $27,30,33$, or $36^{\circ} \mathrm{C}$ for the duration of $0,1,2,3$, or 4 days from the second day of life onwards. The experiment was carried out in four identical environmentallycontrolled wind tunnels. Data on body mass (BM), feed intake (FI), and water intake (WI), all in grams, were monitored daily; and body weight gain (BWG), in grams, and feed conversion (FC) were also calculated. The effect of duration was not statistically significant. Empirical models were adjusted to relate BM, FI, and WI with $t_{\mathrm{db}}$ and bird age. The performance of chicks at 21 days of age was analyzed using the BM, FI, WI, BWG, and $\mathrm{FC}$ values. Overall, the development of chicks at 33 and $36^{\circ} \mathrm{C}$ was better than that of those subjected to the lower $\mathrm{t}_{\mathrm{db}}$ of 30 and $27^{\circ} \mathrm{C}$. The exposure of chicks to cold thermal challenge in early life can have a carry-over negative effect on their production performance up to 21 days of age.
\end{abstract}

Index terms: air temperature, broiler, carry-over effect, production responses, thermal stress.

\section{Desempenho de pintinhos submetidos a estresse térmico}

Resumo - O objetivo deste trabalho foi avaliar o efeito do estresse térmico em diferentes intensidades e durações sobre as respostas produtivas de frangos de corte de 3 a 21 dias de idade. Duzentos e dez pintinhos Cobb foram submetidos às temperaturas do bulbo seco $\left(\mathrm{t}_{\mathrm{bs}}\right)$ de $27,30,33$ ou $36^{\circ} \mathrm{C}$ durante $0,1,2,3$ ou 4 dias, a partir do segundo dia de vida. $\mathrm{O}$ experimento foi conduzido em quatro túneis de vento climatizados idênticos. Dados de massa corporal (MC), consumo de ração (CR) e consumo de água (CAg), todos em gramas, foram coletados diariamente; e ganho de massa corporal (GMC), em gramas, e conversão alimentar (CA) também foram calculados. $\mathrm{O}$ efeito da duração não foi estatisticamente significativo. Modelos empíricos foram ajustados para estimar MC, CR e CAg em função da $t_{b s}$ e da idade das aves. $O$ desempenho dos pintinhos aos 21 dias de idade foi analisado a partir dos valores de MC, CR, CAg, GMC e CA. Em geral, o desenvolvimento de pintinhos a 33 e $36^{\circ} \mathrm{C}$ foi melhor que o dos submetidos às menores $t_{b s}$, de 30 e $27^{\circ} \mathrm{C}$. A exposição de pintos de corte ao frio nos primeiros dias de vida pode causar efeito residual em suas respostas produtivas até 21 dias de idade.

Termos para indexação: temperatura do ar, frango, efeito residual, respostas produtivas, estresse térmico.

\section{Introduction}

Commercial broiler production in Brazil is prominent worldwide, with an annual output of 13.5 million tons of broiler meat (AviSite, 2016). In this context, an efficient production requires adequate indoor thermal conditions throughout the broiler's growth phases (Mostafa et al., 2012).

Suitable environmental conditions are essential during the first week of life of chicks, which tend to have high mortality in this period (Lee et al., 2009).
This is attributed to the fact that newborn chicks are poikilothermic, due to their not yet developed thermoregulatory mechanisms (Mujahid, 2010). As a result, chicks are particularly sensitive to thermal environments outside their comfort range (Moura et al., 2008; Mujahid \& Furuse, 2009; Chowdhury et al., 2012).

Broilers achieve the best performance when reared in thermoneutral conditions. Thermoneutral dry-bulb air temperatures $\left(t_{\mathrm{db}}\right)$ for chicks should range from: 32 to $34^{\circ} \mathrm{C}$ during the first week of life (Cony \& Zocche, 
2004; Oliveira et al., 2006; Pauli et al., 2008); 30 to $32^{\circ} \mathrm{C}$ during the second week; and 26 to $28^{\circ} \mathrm{C}$ during the third week (Cony \& Zocche, 2004). Air velocity should be maintained less than $0.3 \mathrm{~m} \mathrm{~s}^{-1}$ until the birds are fully feathered, in order to avoid chilling by drafts.

When the $t_{d b}$ are below the thermoneutral zone (TNZ), part of the animal's feed energy intake that could be used for growth or production is diverted to thermoregulation to maintain homeostasis. Under severe low $t_{d b}$, chicks can experience hypothermia, decreased alertness, and behavioral and physiological disorders (Mujahid \& Furuse, 2009; Mujahid, 2010). Similarly, $\mathrm{t}_{\mathrm{db}}$ above the TNZ can also have a number of adverse impacts on the animal, such as reduced energy intake and metabolic rate, altered cardiovascular system, and impaired immune function. Furthermore, high $t_{d b}$, in most cases, are accompanied by reduced performance, such as reduced growth rate and elevated mortality (Renaudeau et al., 2012).

Therefore, it is important to quantify the production performance responses of broiler chickens to the thermal environment, in order to better understand this relationship, leading to the enhancement of both animal welfare and production efficiency.

The objective of this work was to evaluate the effect of thermal challenge at different intensities and durations on the production responses of 3 to 21-dayold broiler chickens.

\section{Materials and Methods}

All procedures used in the experiment were approved by the committee on animal research and ethics of Universidade Federal de Lavras (Ufla) (protocol number 001/12).

The experiment was carried out using four identical, thermal environmentally-controlled wind tunnels located at the environmental laboratory of Ufla, in the state of Minas Gerais, Brazil. The wind tunnels were constructed with steel frames, sheets, and polyvinyl chloride (PVC) pipes. The target $\mathrm{t}_{\mathrm{db}}$, relative humidity, and air velocity throughout the 21-day test period were well maintained in the wind tunnels, with a standard deviation of $0.3^{\circ} \mathrm{C}, 0.5 \%$, and $0.10 \mathrm{~m} \mathrm{~s}^{-1}$, respectively. Data on the thermal environment variables in the wind tunnels were controlled, measured, and stored at 1-min intervals using the CR1000 datalogger, which consists of a programmable control and a measurement module (Campbell Scientific, Inc., Logan, UT, USA).

A total of 16 experimental treatments were performed, combining four $t_{d b}\left(27,30,33\right.$, and $\left.36^{\circ} \mathrm{C}\right)$ with four durations of thermal challenge ( 1 to 4 days) (Table 1). All treatments were carried out in four phases, with four treatments evaluated in each one. Performing the experiment in four sequential phases was not expected to affect the experimental results because the environmental conditions within the tunnels were fully controlled and the used chicks were homogenous. The tested chicks had similar initial body mass, came from the same hatchery, and received the same vaccines for Marek's disease, Gumboro disease, and Fowl pox.

The chicks were placed inside the environmentallycontrolled wind tunnels on the day of hatch and remained there until 22 days of age. They were housed in $1 \times 1-\mathrm{cm}$ wire-mesh steel frame cages of $0.40-\mathrm{m}$ width $\times 0.60$-m length $\times 0.50$-m height. Each cage was divided into three equal parts of $0.08 \mathrm{~m}^{2}$ floor area, and the cages were oriented parallel to the direction of the air flow. Therefore, all the birds were subjected to the same thermal conditions.

Due to the amount of space available in the cages, 210 mixed-sex chicks of the Cobb breed were used for the entire experiment. The chicks were randomly distributed among the treatments. Each trial, with four treatments, began with 60 birds, 15 per treatment, distributed in three replicates of 5 birds each. On the eighth day of each 21-day trial, 12 birds were removed from the trial (1 per replicate). Then, on the fifteenth day, another 12 birds were removed from the trial. Therefore, by the end of the trial, 3 birds remained in each replicate. The removed birds were those with the largest deviations in body mass, when compared with the average of the same replicate group. This procedure was used to maintain an appropriate bird stocking density throughout the entire trial and to reflect the housing conditions in commercial broiler production. At the third, eighth, fifteenth, and twentysecond day of age, the average bird stocking densities were of $2.7,7.4,12.3$, and $20 \mathrm{~kg} \mathrm{~m}^{-2}$, respectively. These stocking density values are in alignment with the recommendations of Manning et al. (2007) and Broiler... (2008).

Different numbers of replicates (unbalanced) were used for the control treatments. Specifically, the ninth 
and eleventh treatments had one five-bird replicate with five birds per treatment, whereas the tenth and twelfth treatments each had two five-bird replicates (Table 1). This is the reason why the total number of birds for all the treatments was 210 instead of the expected 240.

Water and commercial feed, with the same formulation, were provided to the birds ad libitum throughout the experimental period.

The chicks were placed in the wind tunnels on the first day of life, upon arrival from the hatchery, with $\mathrm{t}_{\mathrm{db}}$ maintained at $33^{\circ} \mathrm{C}$ (Menegali et al., 2013). Each group of 15 birds housed in the same tunnel was subjected to one of the 16 treatments from the second day of life onwards. Once the thermal challenge was over, air temperature was returned to the thermoneutral level recommended for the first week of life, i.e., $33^{\circ} \mathrm{C}$. During the second and third weeks of life, the birds were subjected to thermoneutral temperatures of 30 and $27^{\circ} \mathrm{C}$, respectively (Menegali et al., 2013). Relative humidity in the wind tunnels was set at $60 \%$ during the entire experimental period (Lin et al., 2005), whereas bird-level air velocity was kept at $0.2 \mathrm{~m} \mathrm{~s}^{-1}$, which was considered comfortable for the age range of the studied birds (Nascimento et al., 2013).

The production performance of the chicks was assessed daily using the following parameters: body mass (BM), feed intake (FI), water intake (WI), body weight gain (BWG), and feed conversion (FC). Data on
BM, FI, WI, BWG, and FC were collected daily from all animals in each treatment. Each replicate had 5, 4, and 3 birds at 1,2, and 3 weeks of age, respectively.

The experimental design was completely randomized and unbalanced, with two replicates for the thermoneutral temperature of $33^{\circ} \mathrm{C}$ and three replicates for the remaining treatments (Table 1). The model considered in the analysis was the following one:

$\mathrm{y}_{\mathrm{ijkl}}=\mu+\tau_{\mathrm{i}}+\delta_{\mathrm{j}}+\tau \delta_{\mathrm{ij}}+\varepsilon_{\mathrm{ijk}}+\gamma_{1}+\tau \gamma_{\mathrm{il}}+\delta \gamma_{\mathrm{jl}}+\tau \delta \gamma_{\mathrm{ijl}}+\varepsilon_{\mathrm{ijk} 1}$

in which $\mathrm{y}_{\mathrm{ijkl}}$ is the value found at age 1 of replicate $\mathrm{k}$ subjected to $t_{d b} i$ for $j$ days of thermal challenge; $\mu$ is a constant inherent to each observation; $\tau_{i}$ is the $t_{d b} i$ effect, with $\mathrm{i}=1,2,3,4 ; \delta_{\mathrm{j}}$ is the effect of duration $\mathrm{j}$, with $\mathrm{j}=1,2,3,4 ; \tau \delta_{\mathrm{ij}}$ is the interaction between $\mathrm{t}_{\mathrm{db}}$ and duration; $\varepsilon_{\mathrm{ijk}}$ is the random error associated with each bird; $\gamma_{1}$ is the effect of age 1 , with $1=1,2, \ldots$, $20 ; \tau \gamma_{\mathrm{il}}$ is the interaction between $\mathrm{t}_{\mathrm{db}}$ and age; $\delta \gamma_{\mathrm{jl}}$ is the interaction between duration and age; $\tau \delta \gamma_{\mathrm{ijl}}$ is the interaction between $t_{\mathrm{db}}$, duration, and age; and $\varepsilon_{\mathrm{ijkl}}$ is the random error associated with the subplot.

Regression models were fitted when the effects were found to be statistically significant because the studied factors were quantitative. These fitted or empirical models were used to estimate the BM, FI, and WI of the birds during the first three weeks of life under different intensities and durations of thermal challenge.

Table 1. The experimental treatments in environmentally-controlled wind tunnels, combining four dry-bulb temperatures and four durations of thermal challenge ${ }^{(1)}$.

\begin{tabular}{|c|c|c|c|c|c|}
\hline \multirow[t]{2}{*}{ Treatment } & \multicolumn{3}{|c|}{ Dry-bulb temperature $\left({ }^{\circ} \mathrm{C}\right)$} & \multirow{2}{*}{$\begin{array}{l}\text { Relative humidity } \\
\text { (\%) }\end{array}$} & \multirow[t]{2}{*}{ Days in thermal challenge } \\
\hline & $1^{\text {st }}$ week $^{(2)}$ & $2^{\text {nd }}$ week & $3^{\text {rd }}$ week & & \\
\hline 1 & $27 \pm 0.2$ & $30 \pm 0.3$ & $27 \pm 0.2$ & $60 \pm 0.3$ & $2^{\text {nd }}$ day of life \\
\hline 2 & $27 \pm 0.3$ & $30 \pm 0.2$ & $27 \pm 0.2$ & $60 \pm 0.3$ & $2^{\text {nd }}$ and $3^{\text {rd }}$ days of life \\
\hline 3 & $27 \pm 0.2$ & $30 \pm 0.2$ & $27 \pm 0.2$ & $60 \pm 0.6$ & $2^{\text {nd }}, 3^{\text {rd }}$, and $4^{\text {th }}$ days of life \\
\hline 4 & $27 \pm 0.2$ & $30 \pm 0.3$ & $27 \pm 0.2$ & $60 \pm 0.3$ & $2^{\text {nd }}, 3^{\text {rd }}, 4^{\text {th }}$, and $5^{\text {th }}$ days of life \\
\hline 5 & $30 \pm 0.3$ & $30 \pm 0.2$ & $27 \pm 0.2$ & $60 \pm 0.4$ & $2^{\text {nd }}$ day of life \\
\hline 6 & $30 \pm 0.3$ & $30 \pm 0.2$ & $27 \pm 0.2$ & $60 \pm 1.0$ & $2^{\text {nd }}$ and $3^{\text {rd }}$ days of life \\
\hline 7 & $30 \pm 0.3$ & $30 \pm 0.2$ & $27 \pm 0.2$ & $60 \pm 0.7$ & $2^{\text {nd }}, 3^{\text {rd }}$, and $4^{\text {th }}$ days of life \\
\hline 8 & $30 \pm 0.2$ & $30 \pm 0.2$ & $27 \pm 0.2$ & $60 \pm 0.3$ & $2^{\text {nd }}, 3^{\text {rd }}, 4^{\text {th }}$, and $5^{\text {th }}$ days of life \\
\hline $9,10,11,12$ (control) & $33 \pm 0.2$ & $30 \pm 0.3$ & $27 \pm 0.2$ & $60 \pm 0.5$ & No day on week 1 \\
\hline 13 & $36 \pm 0.6$ & $30 \pm 0.3$ & $27 \pm 0.6$ & $60 \pm 0.3$ & $2^{\text {nd }}$ day of life \\
\hline 14 & $36 \pm 0.5$ & $30 \pm 0.2$ & $27 \pm 0.5$ & $60 \pm 1.0$ & $2^{\text {nd }}$ and $3^{\text {rd }}$ days of life \\
\hline 15 & $36 \pm 0.6$ & $30 \pm 0.3$ & $27 \pm 0.6$ & $60 \pm 0.5$ & $2^{\text {nd }}, 3^{\text {rd }}$, and $4^{\text {th }}$ days of life \\
\hline 16 & $36 \pm 0.5$ & $30 \pm 0.2$ & $27 \pm 0.6$ & $60 \pm 0.4$ & $2^{\text {nd }}, 3^{\text {rd }}, 4^{\text {th }}$, and $5^{\text {th }}$ days of life \\
\hline
\end{tabular}

Chicks/Treatment $\quad 15 \quad 12 \quad 8$

(1)Air velocity at the animal-occupied zone was $0.2 \pm 0.1 \mathrm{~m} \mathrm{~s}^{-1}$. (2)Air temperature for the remainder of the first week, after the thermal challenge, was maintained at the thermoneutral level of $33^{\circ} \mathrm{C}$. 
The models were selected considering performance and biological explanation. Therefore, BM, FI, and WI may be estimated based on: the $t_{d b}$ to which the animals were subjected, which ranged from 27 to $36^{\circ} \mathrm{C}$; the duration of the thermal challenge from the second day of life onwards, which was of $1,2,3$, or 4 days; and the age of the birds, from 3 to 21 days of life. It should be noted that data from the first and second day of life were excluded in the regression analysis because these days were considered as the acclimation period.

The accumulative means of bird productive responses were used to evaluate the treatment effect on BM, FI, WI, BWG, and FC. Data were subjected to the analysis of variance, and means were compared by Tukey's test, at $5 \%$ probability.

Statistical analyses were performed using the Proc REG and Proc Mixed procedures of the SAS software, version 9.3 (SAS Institute Inc., Cary, NC, USA).

\section{Results and Discussion}

BM, FI, and WI showed a two-way interaction between $t_{d b}$ and age $(p<0.01)$. Multivariable regression models were fitted to relate the production performance responses to these two factors. BWG showed a threeway interaction between $t_{d b}$, duration, and age $(p<0.01)$, and the multivariable regression models were fitted accordingly. However, in this last case, the resultant models were not statistically significant $(p>0.05)$ and, therefore, were not used to estimate the variable.

The regression models fitted for the BM, FI, and WI equations below, respectively, were the most adequate in delineating functional relationships $(\mathrm{p}<0.01)$. These models are valid for birds from 3 to 21 days of age and subjected to $t_{\mathrm{db}}$ from 27 to $36^{\circ} \mathrm{C}$. The standard errors (between brackets) of the estimated parameters of the model indicate the degree of uncertainty in the estimation:

$\mathrm{BM}=5.0748(0.3305) \times \mathrm{t}_{\mathrm{db}}+25.0786(0.2132) \times$ Age 220.1379 (10.7145);

$\mathrm{FI}=0.68984(0.0883) \times \mathrm{t}_{\mathrm{db}}+5.03152(0.0570) \times$ Age 23.11542 (2.8643);

$\mathrm{WI}=1.09 \times \mathrm{t}_{\mathrm{db}}(0.1730)+10.2354 \times$ Age $(0.1116)-$ 24.7531 (5.6102).

The correlation coefficients $\left(\mathrm{R}^{2}\right)$ of the regression models were $0.934,0.933$, and 0.935 for BM, FI, and WI, respectively. This means that only $6.6 \%$ of the variability in $\mathrm{BM}, 6.7 \%$ in $\mathrm{FI}$, and $6.5 \%$ in WI was not explained by the fitted models. These relatively small deviations between the observed and estimated values could have resulted from random errors that were not necessarily attributable to the model factors (Kelkinnama \& Taheri, 2012).

Araujo et al. (2011) developed response surface models to estimate BWG and FI as a function of $t_{d b}$, metabolizable energy of feed, and age of animals at slaughter, yielding $\mathrm{R}^{2}$ values of 0.88 and 0.87 , respectively. In the present study, the models obtained showed reasonable accuracy for predicting BM, FI, and WI of chicks from 3 to 21 days of life subjected to the thermal condition treatments, when compared with models of similar nature reported in the literature.

A graph of model-predicted values versus observed values allows visualizing the model's bias. Such a graph should appear as a straight line in the case of an unbiased model (Faria Filho et al., 2008). This shows that the adjusted models provided good approximation of the actual values for BM, FI, and WI (Figure 1).

The response surface graphs to predict BM, FI, and WI are merely regression models as a function of two explanatory variables or factors; in this case, of $t_{d b}$ and bird age. The response surfaces provided a more vivid depiction of BM, FI, and WI as affected by age and $t_{d b}$ (Figure 2).

The results obtained by Tukey's test revealed that $\mathrm{BM}, \mathrm{FI}, \mathrm{WI}, \mathrm{BWG}$, and FC were not significantly affected by the duration of the thermal challenge. The corresponding $\mathrm{p}$-values were 0.2638 for $\mathrm{BM}, 0.8366$ for FI, 0.8920 for WI, 0.2905 for BWG, and 0.6344 for FC (Table 2).

At 21 days of age, the chicks subjected to low $t_{d b}$, especially of $27^{\circ} \mathrm{C}$, showed a significantly lower BWG than those subjected to the other $t_{d b}(p<0.05)$ (Figure $2 \mathrm{~A}$ and Table 2). This result indicates that $27^{\circ} \mathrm{C}$ is unconducive for chicks in the first week of life, confirming the findings of Carvalho et al. (2011). These authors reported that thermal challenge affects animal productivity since heat exchange with the environment alters BWG and, consequently, nutrient metabolism.

The lowest $\mathrm{BM}$ was also observed for chicks subjected to $27^{\circ} \mathrm{C}(\mathrm{p}<0.05)$ (Figure $2 \mathrm{~A}$ and Table 2). Moura et al. (2008) pointed out that low $t_{d b}$ in the first days of life may impair both bird development and health. This can be explained by the fact that chicks have a large body surface area to volume ratio, making 

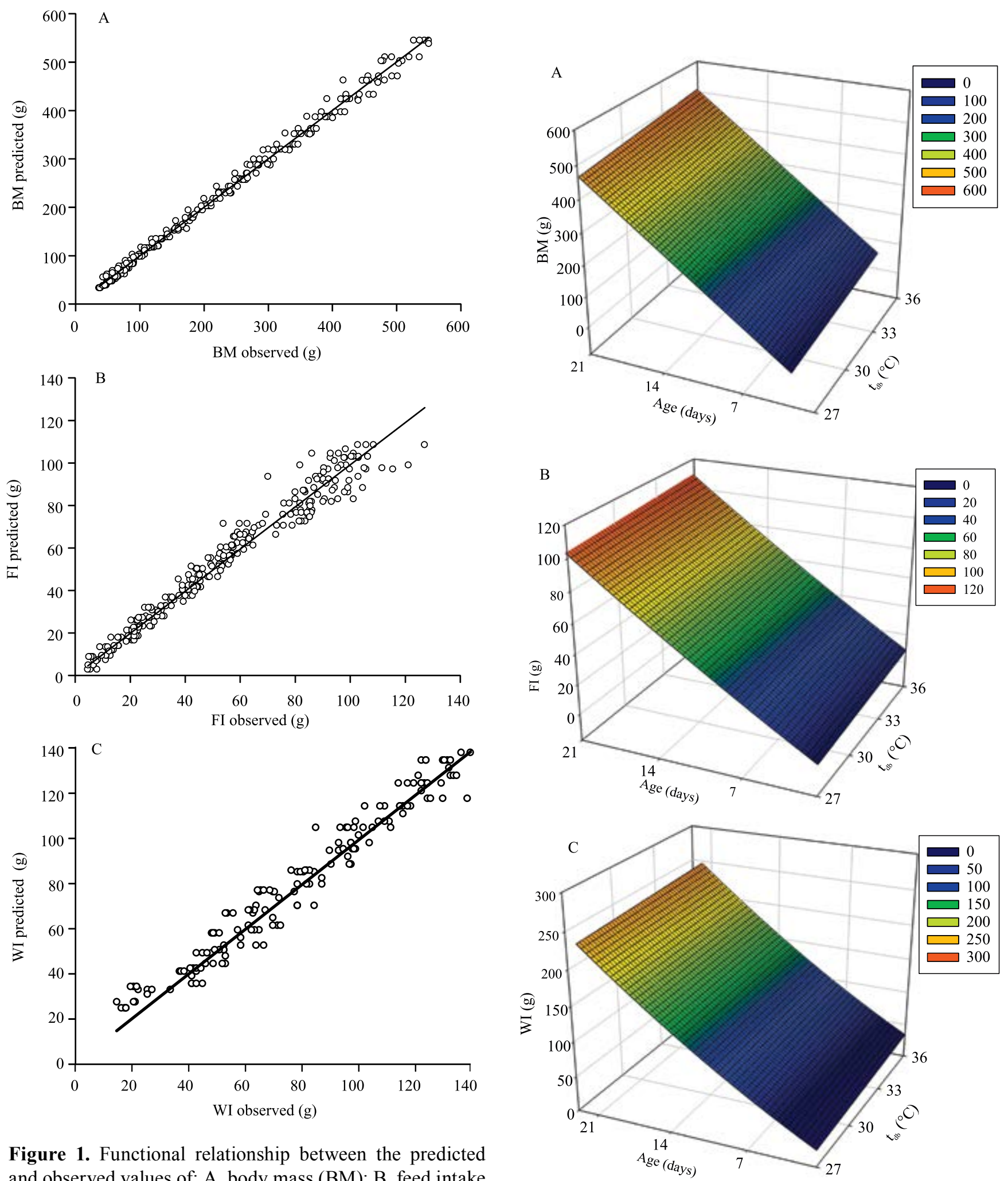

Figure 1. Functional relationship between the predicted and observed values of: $\mathrm{A}$, body mass (BM); B, feed intake (FI); and C, water intake (WI) of broiler chickens under the experimental conditions: dry-bulb temperature from 27 to $36^{\circ} \mathrm{C}$, bird age from 3 to 21 days, and thermal challenge duration of 1 to 4 days.

Figure 2. Response surfaces of: A, body mass (BM); B, feed intake (FI); and C, water intake (WI) of broiler chickens as a function of dry-bulb temperature $\left(\mathrm{t}_{\mathrm{db}}\right)$ and bird age. 
them less effective in conserving body heat. Indeed, the thermoregulatory system of chicks is not fully developed in the first week of life, indicating the need for higher environmental temperatures for young birds to maintain normal core temperature (Cordeiro et al., 2010; Nazareno et al., 2015). Therefore, air temperatures below the thermal requirements will inevitably cause financial losses because a higher portion of the feed energy is diverted to thermoregulation or the survival of the animal as opposed to production (Schiassi et al., 2015)

The largest BM was obtained for chicks subjected to $33^{\circ} \mathrm{C}$ - the recommended comfortable $t_{\mathrm{db}}$ for this age (Cony \& Zocche, 2004) - and to $36^{\circ} \mathrm{C}(\mathrm{p}<0.05)$. Therefore, the results show that $36^{\circ} \mathrm{C}$ does not pose heat stress to the chicks as their performance was very similar to that of the those subjected to $33^{\circ} \mathrm{C}$ $(\mathrm{p}=0.8711)$.

The chicks subjected to low $t_{d b}$ had a lower FI than the ones under the comfortable $\mathrm{t}_{\mathrm{db}}$, of 33 and $36^{\circ} \mathrm{C}$ (Figure $2 \mathrm{~B}$ and Table 2), which, in turn, led to a lower BWG. According to Mujahid \& Furuse (2009), cold stress adversely affects the FI of chicks because of its impact on the digestive system and body development. In a commercial broiler facility where lower $t_{d b}$ may exist in parts of the house, BWG differences will cause increased nonuniformity of the flock and, consequently, financial losses (Khan et al., 2011, 2012).

WI increased with increasing $\mathrm{t}_{\mathrm{db}}$ during the 21 days of life of the chicks $(\mathrm{p}<0.05)$ (Figure $2 \mathrm{C}$ and Table 2$)$. Nielsen (2012) stated that heat dissipation has an important effect on bird WI and growth. Under warm/ hot environments, the WI by birds is greater because it is essential to the cooling mechanisms (increased latent

Table 2. Cumulative body mass (BM), feed intake (FI), water intake (WI), body weight gain (BWG), and feed conversion (FC) of 21-day-old broiler chickens under each evaluated dry-bulb temperature $\left(\mathrm{t}_{\mathrm{db}}\right)^{(1)}$.

\begin{tabular}{lccccc}
\hline $\begin{array}{l}\mathrm{t}_{\mathrm{db}} \\
\left({ }^{\circ} \mathrm{C}\right)\end{array}$ & $\begin{array}{c}\mathrm{BM} \\
(\mathrm{g})\end{array}$ & $\begin{array}{c}\text { FI } \\
(\mathrm{g})\end{array}$ & $\begin{array}{c}\text { WI } \\
(\mathrm{g})\end{array}$ & $\begin{array}{c}\text { BWG } \\
(\mathrm{g})\end{array}$ & FC \\
\hline 27 & $455.0 \mathrm{c}$ & $1,061.7 \mathrm{~b}$ & $2,430.5 \mathrm{~b}$ & $417.4 \mathrm{~b}$ & 2.550 \\
30 & $507.0 \mathrm{~b}$ & $1,135.4 \mathrm{ab}$ & $2,606.9 \mathrm{ab}$ & $462.5 \mathrm{a}$ & 2.467 \\
33 & $553.0 \mathrm{a}$ & $1,186.0 \mathrm{a}$ & $2,595.6 \mathrm{ab}$ & $506.2 \mathrm{a}$ & 2.325 \\
36 & $539.0 \mathrm{a}$ & $1,184.9 \mathrm{a}$ & $2,660.7 \mathrm{a}$ & $492.3 \mathrm{a}$ & 2.408 \\
\hline Average & 507.3 & $1,134.5$ & $2,568.7$ & 463.8 & 2.459 \\
CV $(\%)$ & 0.01 & 0.09 & 7.91 & 0.22 & 0.25 \\
\hline
\end{tabular}

${ }^{(1)}$ Means followed by equal letters, in the columns, do not differ significantly by Tukey's test, at $5 \%$ probability. CV, coefficient of variation. heat loss) involved in thermoregulation (Cordeiro et al., 2010).

Although better results for BM, FI, WI, and BWG were found at $t_{d b}$ of 33 and $36^{\circ} \mathrm{C}$, no significant differences were observed for $\mathrm{FC}$ among the $\mathrm{t}_{\mathrm{db}}$ evaluated $(\mathrm{p}=0.1794)$ (Table 2). Overall, the performance of chicks at 33 and $36^{\circ} \mathrm{C}$ was better than that under 30 and $27^{\circ} \mathrm{C}$ during the first week of life. This shows that the development of birds subjected to cold challenge in the first few days of life may be delayed and may not be recovered adequately, as reported by Cordeiro et al. (2010). According to Abreu et al. (2012), young birds have a higher resistance to heat and a greater susceptibility to cold stress. This result was supported by those of the present study, in which birds initially subjected to $36^{\circ} \mathrm{C}$ performed better than those at the cooler $\mathrm{t}_{\mathrm{db}}$ of 27 or $30^{\circ} \mathrm{C}$.

Although the scale of the current study is far from that of commercial farms, the obtained results can still be used as reference values for decision-making regarding the proper environmental conditions to give chicks a good start in the brooding period. It should be highlighted that a relative short exposure of thermal stress may be as detrimental to the birds as a long one.

\section{Conclusions}

1. The exposure of broiler chickens to cold thermal challenge early in life shows a carry-over effect on body mass, feed intake, water intake, and body weight gain until 21 days of age.

2. The production performance of broiler chickens subjected to a draft-free environment at 33 and $36^{\circ} \mathrm{C}$ dry-bulb temperatures, under $60 \%$ relative humidity, is similar.

3. The empirical models perform well in estimating body mass, feed intake, and water intake of broiler chickens as a function of dry-bulb temperature and bird age.

\section{Acknowledgments}

To Conselho Nacional de Desenvolvimento Científico e Tecnológico (CNPq), to Fundação de Amparo à Pesquisa do Estado de Minas Gerais (Fapemig), and to Coordenação de Aperfeiçoamento de Pessoal de Nível Superior (Capes), for financial support. 


\section{References}

ABREU, P.G. de; ABREU, V.M.N.; COLDEBELLA, A.; HASSEMER, M.J.; TOMAZELLI, I.L. Medidas morfológicas em função do peso e da idade da ave, por meio de imagens. Revista Brasileira de Engenharia Agrícola e Ambiental, v.16, p.795801, 2012. DOI: $10.1590 / \mathrm{S} 1415-43662012000700014$.

ARAUJO, R.B.; FARIA FILHO, D.E. de; FARIA FILHO, D.E. de; LIMA, C.G. de; TREVISAN, R.B.; SOUZA, K.M.R. de; SAKAMOTO, M.I.; SOUZA, V.N. de. Modelos de superfície de resposta para predição do desempenho de frangos e elaboração de análise econômica. Revista Brasileira de Saúde e Produção Animal, v.12, p.770-783, 2011.

AVISITE: estatísticas e preços: produção de carne de frango em mil ton. 2016. Available at: $<$ http://www.avisite.com.br/economia/ index.php?acao $=$ carnefrango $>$. Accessed on: Aug. 82016.

BROILER management guide. Siloam Springs: Cobb-Vantress, 2008. 70p.

CARVALHO, F.B.; SARTORI, J.R.; STRINGHINI, J.H.; FASCINA, V.B.; PEREIRA, L.A.; PELÍCIA, V.C. Efeito da temperatura ambiente e da idade do frango sobre o valor energético do farelo de soja. Arquivo Brasileiro de Medicina Veterinária e Zootecnia, v.63, p.1437-1445, 2011. DOI: 10.1590/ S0102-09352011000600022.

CHOWDHURY, V.S.; TOMONAGA, S.; NISHIMURA, S.; TABATA, S.; FURUSE, M. Physiological and behavioral responses of young chicks to high ambient temperature. The Journal of Poultry Science, v.49, p.212-218, 2012. DOI: 10.2141/ jpsa.011071.

CONY, A.V.; ZOCCHE, A.T. Equipamentos para fornecimento de ração e água. In: MENDES, A.A.; NÄÄS, I. de A.; MACARI, M. (Ed.). Produção de frangos de corte. Campinas: Fundação Apinco de Ciência e Tecnologia Avícolas, 2004. p.97-106.

CORDEIRO, M.B.; TINÔCO, I. de F.F.; SILVA, J.N. da; VIGODERIS, R.B.; PINTO, F. de A. de C.; CECON, P.R. Thermal comfort and performance of chicks submitted to different heating systems during winter. Revista Brasileira de Zootecnia, v.39, p.217-224, 2010. DOI: 10.1590/S1516-35982010000100029.

FARIA FILHO, D.E.; ROSA, P.S.; TORRES, K.A.A.; MACARI, M.; FURLAN, R.L. Response surface models to predict broiler performance and applications for economic analysis. Revista Brasileira de Ciência Avícola, v.10, p.131-138, 2008. DOI: 10.1590/S1516-635X2008000200009.

KELKINNAMA, M.; TAHERI, S.M. Fuzzy least-absolutes regression using shape preserving operations. Information Sciences, v.214, p.105-120, 2012. DOI: 10.1016/j.ins.2012.04.017.

KHAN, R.U.; NAZ, S.; NIKOUSEFAT, Z.; SELVAGGI, M.; LAUDADIO, V.; TUFARELLI, V. Effect of ascorbic acid in heatstressed poultry. World's Poultry Science Journal, v.68, p.477489, 2012. DOI: 10.1017/S004393391200058X.

KHAN, R.U.; NAZ, S.; NIKOUSEFAT, Z.; TUFARELLI, V.; JAVDANI, M.; RANA, N.; LAUDADIO, V. Effect of vitamin E in heat-stressed poultry. World's Poultry Science Journal, v.67, p.469-478, 2011. DOI: 10.1017/S0043933911000511.
LEE, I.-B.; SASE, S.; HAN, H.-T.; HONG, H.-K.; SUNG, S.H.; HWANG, H.-S.; HONG, S.-W.; SEO, I.-H.; KWON, S.-H. Ventilation design for a chick incubator using computational fluid dynamics. Japan Agricultural Research Quarterly, v.43, p.227237, 2009. DOI: 10.6090/jarq.43.227.

LIN, H.;ZHANG, H.F.; JIAO, H.C.; ZHAO, T.; SUI, S.J.; GU, X.H.; ZHANG, Z.Y.; BUYSE, J.; DECUYPERE, E. Thermoregulation responses of broiler chickens to humidity at different ambient temperatures. I. One week of age. Poultry Science, v.84, p.11661172, 2005. DOI: 10.1093/ps/84.8.1166.

MANNING, L.; CHADD, S.A.; BAINES, R.N. Key health and welfare indicators for broiler production. World's Poultry Science Journal, v.63, p.46-62, 2007. DOI: 10.1017/s0043933907001262.

MENEGALI, I.; TINOCO, I.F.F.; CARVALHO, C. da C.S.; SOUZA, C. de F.; MARTINS, J.H. Comportamento de variáveis climáticas em sistemas de ventilação mínima para produção de pintos de corte. Revista Brasileira de Engenharia Agrícola e Ambiental, v.17, p.106-113, 2013. DOI: 10.1590/S141543662013000100015.

MOSTAFA, E.; LEE, I.-B.; SONG, S.-H.; KWON, K.-S.; SEO, I.-H.; HONG, S.-W.; HWANG, H.-S.; BITOG, J.P.; HAN, H.-T. Computational fluid dynamics simulation of air temperature distribution inside broiler building fitted with duct ventilation system. Biosystems Engineering, v.12, p.293-303, 2012. DOI: 10.1016/j.biosystemseng.2012.05.001.

MOURA, D.J.de; NÄÄS, I.deA.;ALVES,E.C.deS.;CARVALHO, T.M.R. de; VALE, M.M. do; LIMA, K.A.O. de. Noise analysis to evaluate chick thermal comfort. Scientia Agricola, v.65, p.438443, 2008. DOI: 10.1590/S0103-90162008000400018.

MUJAHID, A. Acute cold-induced thermogenesis in neonatal chicks (Gallus gallus). Comparative Biochemistry and Physiology Part A: Molecular and Integrative Physiology, v.156, p.34-41, 2010. DOI: 10.1016/j.cbpa.2009.12.004.

MUJAHID, A.; FURUSE, M. Behavioral responses of neonatal chicks exposed to low environmental temperature. Poultry Science, v.88, p.917-922, 2009. DOI: 10.3382/ps.2008-00472.

NASCIMENTO, S.T.; SILVA, I.J.O. da; MAIA, A.S.C.; CASTRO, A.C. de; VIEIRA, F.M.C. Mean surface temperature prediction models for broiler chickens - a study of sensible heat flow. International Journal of Biometeorology, v.57, p.1-6, 2013. DOI 10.1007/s00484-013-0702-7.

NAZARENO, A.C.; SILVA, I.J.O. da; VIEIRA, F.M.C.; SANTOS, R.F.S. Temperature mapping of trucks transporting fertile eggs and day-old chicks: efficiency and/or acclimatization? Revista Brasileira de Engenharia Agrícola e Ambiental, v.19, p.134139, 2015. DOI: 10.1590/1807-1929/agriambi.v19n2p134-139.

NIELSEN, B.L. Effects of ambient temperature and early openfield response on the behaviour, feed intake and growth of fastand slow-growing broiler strains. Animal, v.6, p.1460-1468, 2012. DOI: $10.1017 / \mathrm{S} 1751731112000353$.

OLIVEIRA, R.F.M. de; DONZELE, J.L.; ABREU, M.L.T. de; FERREIRA, R.A.; VAZ, R.G.M.V.; CELLA, P.S. Efeitos da temperatura e da umidade relativa sobre o desempenho e o rendimento de cortes nobres de frangos de corte de 1 a 49 dias de 
idade. Revista Brasileira de Zootecnia, v.35, p.797-803, 2006. DOI: 10.1590/S1516-35982006000300023.

PAULI, D.G. de; SILVA, J.N. da; VIGODERIS, R.B.; TINOCO, I. de F.F.; IORIO, V.O. de; GALVARRO, S.F.S. Desenvolvimento de um software para dimensionamento de sistemas de ventilação e resfriamento evaporativo em instalações avícolas climatizadas. Engenharia na Agricultura, v.16, p.167-179, 2008. DOI: 10.13083/1414-3984.v16n02a04.
RENAUDEAU, D.; COLLIN, A.; YAHAV, S.; BASILIO, V. de; GOURDINE, J.L.; COLLIER, R.J. Adaptation to hot climate and strategies to alleviate heat stress in livestock production. Animal, v.6, p.707-728, 2012. DOI: 10.1017/S1751731111002448.

SCHIASSI, L.; YANAGI JUNIOR, T.; FERRAZ, P.F.P.; CAMPOS, A.T.; SILVA, G.R. e; ABREU, L.H.P. Comportamento de frangos de corte submetidos a diferentes ambientes térmicos. Engenharia Agrícola, v.35, p.390-396, 2015. DOI: 10.1590/18094430-Eng.Agric.v35n3p390-396/2015.

$\overline{\text { Received on February 10, } 2016 \text { and accepted on August 10, } 2016}$ 